\title{
Susceptibility Pattern of ESBL Urine Specimens in Non-Intensive Care Room at Ulin General Hospital
}

\author{
Alicia Fitri Wulandhany ${ }^{1}$, Dewi Indah Noviana Pratiwi' ${ }^{2}$ Noor Muthmainah ${ }^{3}$, Agung Biworo ${ }^{4}$ \\ ${ }^{1}$ Medical Education Study Program, Faculty of Medicine, Lambung Mangkurat University, Indonesia. E-mail: aliciawulan@gmail.com \\ 2 Department of Clinical Pathology, Faculty of Medicine, Lambung Mangkurat University/Ulin General Hospital Banjarmasin, Indonesia \\ ${ }^{3}$ Department of Microbiology, Faculty of Medicine, Lambung Mangkurat University Banjarmasin, Indonesia \\ ${ }^{4}$ Department of Pharmacology, Faculty of Medicine, Lambung Mangkurat University Banjarmasin, Indonesia
}

\begin{abstract}
Beta-lactam antibiotic resistance can occur in ESBL-producing bacteria such as E.coli and K.pneumoniae, which can cause UTI. One of the risk factors for infection is the non-intensive care space density level. The objective of this study was to determine the sensitivity pattern of ESBL-producing bacteria in urine specimens of patients in the non-intensive care of Ulin General Hospital, Banjarmasin, in the period of 2016-2018. A descriptive study with a cross-sectional design using data results of urine culture and antibiotic susceptibility patterns data in non-intensive care patients at Ulin General Hospital from 2016 to 2018. The urine test results showed 96 positive isolates of ESBL-producing bacteria, consisting of ESBL-E.coli (69.8\%) and ESBL-K.pneumonia (30.2\%). Antibiotics with low sensitivity tests were Penicillin, Cephalosporin, Monobactam, and Penicillin/beta-lactam inhibitor combinations. Contrastingly, antibiotics with high sensitivity were Aminoglycoside, Carbapenem, and Glycylcycline. It was concluded from this study that the ESBL-producing bacteria in urine specimens for non-intensive care patients of Banjarmasin Ulin General Hospital in the period of 2016-2018 showed varying sensitivity to antibiotics.
\end{abstract}

Keywords: ESBL, non-intensive care room, susceptibility pattern, urine

\section{INTRODUCTION}

Antibiotic resistance has become one of the three most dangerous public health threats of the $21^{\text {st }}$ century. One of the cases is the resistance of beta-lactam antibiotics, especially against Gram-negative bacteria that can occur at various levels, such as resistance to Extended-Spectrum Beta-Lactamase (ESBL)-producing bacteria. ${ }^{1,2}$ The most found ESBL-producing bacteria are E.coli and K.pneumoniae. ${ }^{3}$ Surveillance of the RSDS-Balitbangkes-WHO Antimicrobial Resistance Control Program in 2013 showed that the prevalence of ESBL in several national referral hospitals in Indonesia ranged from 32.1-56.8\% for K.pneumonia and $26.7-56.8 \%$ for E.coli. ${ }^{4}$ Both of these bacteria play an important role in causing various kinds of infections such as bacteremia, infections of the central nervous system, Urinary Tract Infections (UTI), diarrhea, and severe nosocomial infections. One of the severe nosocomial infections is nosocomial UTI due to a three-way catheter and the duration of catheter use. ${ }^{5,6}$ If nosocomial infections are not prevented, infections can be spread in the hospital environment or the family and the broader community due to a lack of attention to infection control measures.' Non-intensive care rooms are treatment rooms that provide higher-class care than intensive care rooms, commonly called wards or inpatients. ${ }^{8}$ The density level of an inpatient room space illustrates one of the risk factors for nosocomial infections because the more significant number of patients in an area is one of the causes of improper performance of septic and antiseptic procedures. ${ }^{9}$ The increased spread of infection leads to an increased number of cases of the disease, such as ESBL infection. Consequently, morbidity, mortality, and health care costs will increase.

This study aimed to determine the sensitivity pattern of ESBL-producing bacteria to antibiotics from urine specimens in the non-intensive care room of Ulin General Hospital, Banjarmasin, from 2016 to 2018. This research was expected to provide information about the percentage of ESBL-producing bacteria, the sensitivity of ESBL-producing bacteria to antibiotics, and antibiotics that are still sensitive to ESBL-producing bacteria in urine specimens in Ulin General Hospital from 2016 to 2018. Data regarding cases of ESBL-producing bacterial resistance of non-intensive care patients in Indonesia, especially in 
urine specimens, is still limited. Therefore, further data are still needed.

\section{METHODS}

This study was a descriptive observational study with a cross-sectional design by taking secondary data of patients with ESBL infection whose urine culture test results and positive culture results on urine specimens in the non-intensive care of Ulin General Hospital, Banjarmasin in a period of 2016-2018. The results of bacterial antibiotics susceptibility were identified automatically using the VITEK ${ }^{\circledR} 2$ Compact. The results were validated and interpreted according to the Clinical Laboratory Standard Institute (CLSI).

This study was approved by the Ethics Committee of Ulin General Hospital, Banjarmasin, with ethical clearance number 202/VIII-Reg Riset/RSUDU/19 and by the Committee of Medical Research Ethics of Medical Faculty, Lambung Mangkurat University, with ethical clearance number 445/KEPK-FK UNLAM/EC/IX/2019.

\section{RESULTS AND DISCUSSIONS}

Research on "sensitivity pattern of ESBL-producing bacteria in non-intensive care room Ulin General Hospital in the period of 2016-2018" has been carried out at the Clinical Pathology Laboratory of Ulin
General Hospital, Banjarmasin. This research was conducted by taking laboratory-based secondary data, such as the culture test results of ESBL-producing bacteria from urine specimens of patients in the non-intensive care room from 2016-2018. Through the culture data, the number of urine culture tests in Ulin General Hospital and non-intensive care room for the period of 2016-2018 is shown in Table 1.

Table 1 shows that from 1020 urine culture isolates in Ulin General Hospital. There were 553 isolates (54.22\%) for urine culture examinations in the non-intensive care room. 225 out of 553 isolates for the number of bacterial-positive urine cultures in the non-intensive care room. From 255 positive isolates in the non-intensive care room for bacterial growth consisted of 97 isolates (38\%) E.coli, 45 isolates (17.65\%) K.pneuomoniae, and 113 isolates (44.31\%) other bacteria.

ESBL-producing bacteria from urine specimens in patients in the non-intensive care room were generally E.coli and K.pneumoniae. Data on the number of isolates and ESBL of E.coli and K.pneumoniae in the non-intensive care room of the urine specimen are presented in Table 2.

Table 2 shows that out of 97 E.coli isolates, 67 isolates (69.07\%) were ESBL positive, whereas, of 45 K.pneumoniae isolates, 29 isolates (64.44\%) were ESBL-positive. E.coli caused bacteriuria more frequently compared to K.pneumoniae. The results

Table 1. The number of urine culture examinations in Ulin General Hospital, number of urine culture examinations in non-intensive care rooms, and number of urine cultures (+) in non-intensive care rooms in the period of $2016-2018$

\begin{tabular}{cccccc}
\hline Year & $\begin{array}{c}\text { Number of Urine Culture } \\
\text { Examination in Ulin } \\
\text { General Hospital }\end{array}$ & $\begin{array}{c}\text { Number of Urine Culture } \\
\text { Examination in Non-intensive } \\
\text { Care Room }\end{array}$ & $\begin{array}{c}\text { Number of Urine } \\
\text { Culture (+) in Non-intensive } \\
\text { Care Room }\end{array}$ \\
\cline { 3 - 6 } & 267 & $\mathrm{~N}$ & $\%$ & $\mathrm{~N}$ & $\%$ \\
\hline 2016 & 350 & 190 & 71.1 & 82 & 43.16 \\
2017 & 403 & 182 & 52 & 83 & 45.6 \\
2018 & 403 & 44.91 & 90 & 49.72 \\
\hline
\end{tabular}

Table 2. Total isolates and ESBL of E.coli and K.pneumoniae in the non-intensive care room from the urine specimens

\begin{tabular}{cccccccc}
\hline & \multicolumn{3}{c}{ Total } & \multicolumn{3}{c}{ ESBL } \\
\cline { 2 - 7 } Year & E.coli & K.pneumoniae & & E.coli & \multicolumn{2}{c}{ K.pneumoniae } \\
\cline { 2 - 7 } & $\mathrm{N}$ & $\mathrm{N}$ & $\mathrm{N}$ & $\%$ & $\mathrm{~N}$ & $\%$ \\
\hline 2016 & 30 & 22 & 18 & 60 & 18 & 81.82 \\
2017 & 33 & 12 & 22 & 66.67 & 5 & 41.67 \\
2018 & 34 & 11 & 27 & 79.41 & 6 & 54.55 \\
\hline
\end{tabular}


Table 3. The number of ESBL-producing bacteria from urine specimens in the non-intensive care room

\begin{tabular}{ccccccc}
\hline & \multicolumn{7}{c}{ Year } \\
\cline { 2 - 7 } $\begin{array}{c}\text { Bacterial Colonies } \\
\text { (CFU/mL) }\end{array}$ & $\mathrm{N}$ & $\%$ & $\mathrm{~N}$ & $\%$ & $\mathrm{~N}$ & $\%$ \\
\cline { 2 - 7 } & 2 & 2.2 & 7 & 7.69 & 13 & 14.29 \\
$\geq 10^{2}$ & - & - & 4 & 4.4 & - & - \\
$\geq 10^{3}$ & 4 & 4.4 & - & - & - & - \\
$\geq 10^{4}$ & 29 & 31.87 & 12 & 13.2 & 20 & 21.98 \\
$\geq 10^{5}$ & 35 & 38.46 & 23 & 25.27 & 33 & 36.26 \\
\hline Total & & & & &
\end{tabular}

of this study were similar to a study in Ethiopia in 2016 on urine specimens of UTI patients, which showed that E.coli was the most common ESBL-producing bacteria in urine specimens (76.5\%) compared to K.pneumoniae (23.5\%). ${ }^{10}$

E.coli is a normal flora of the digestive tract that can enter the urinary tract through ascending, hematogenous, lymphogenic, and direct transmission from surrounding organs that were previously infected. ${ }^{11}$ Infection (uropathogenic) acts as an agent, while urinary tract epithelium acts as a host. However, decreased host defense or increased virulence agent can impair the balance between agent and host. Host factors such as lowered local defenses, decreased immune system, and several conditions such as diabetes mellitus, elderly, pregnancy, immunosuppressive diseases can facilitate the emergence of UTI. Local defenses of the host are reduced due to disruption of the process of washing out of urine, such as the use of catheter urine, decreased estrogen during menopause, increased acidity of the urine, decreased uromucoid, and so on. Some microorganisms produce toxins, which act as another factor. E.coli, for example, has a toxin called alpha-hemolysin, which causes inflammation, and it possesses Pili to facilitate attachment to urinary uroepithelium because the uromucoid in the urine cannot bind to pili $P^{12,13}$

Urine culture is a basic laboratory test for patients suspected of renal impairment or UTI. ${ }^{14}$ Urinary culture can be an indicator of complicated UTI including pyelonephritis, UTI for the past three weeks (suspected relapse), or symptoms persisting for more than seven days, hospitalized patients or catheterization, kidney transplant patients, immunosuppressed patients, prostatitis patients, pregnant patients, and diabetes mellitus patients. ${ }^{15}$ In the study, it was found that bacterial colonies $\geq 105$ were more common than the number of other bacterial colonies. The distribution of the ESBL-producing bacteria from urine specimens in the non-intensive care room is presented in Table 3.
Table 3 presents data on the number of bacterial colonies in urine. Bacterial colonies $\geq 105$ might be related to the collection of urine specimens by midstream urine with a differential diagnosis of asymptomatic bacteriuria and UTI complications. ${ }^{16}$ Bacterial colony $\geq 104$ can be attributed to the use of midstream urine with a differential diagnosis of acute uncomplicated pyelonephritis and complicated UTI in men and the use of a catheter sample with a differential diagnosis of UTI complications in women. Bacteriuria $\geq 103$ can be attributed to midstream urine, which has a differential diagnosis of non-complicated cystitis and acute uncomplicated UTI in women. ${ }^{16,17}$ Bacterial colony $\geq 102$ in urine can be attributed to this asymptomatic bacteriuria caused by the use of urine catheter. $^{17}$

The sensitivity pattern of ESBL-producing E.coli from urine specimens in the non-intensive care room of Ulin General Hospital in 2016-2018 can be seen in Figure 1, while the sensitivity pattern of ESBL-producing K.pneumoniae bacteria from urine specimens in the non-intensive care room of Ulin General Hospital in 2016-2018 can be seen in Figure 2.

It was found from the results that the ESBL-producing E.coli and K.pneumoniae showed low sensitivity to Penicillin (Ampicillin) antibiotics, cephalosporin (Cephazolin, Cefazolin, Cefepime, Ceftazidime, and (eftriaxone) antibiotics, Aztreonam, and a combination of beta-lactam antibiotics/inhibitor beta-lactamase inhibitor (Ampicillin/Sulbactam) from year to year. This was similar to research in China in 2016-2017 showing high resistance of ESBL-producing E.coli and K.pneumoniae to Ceftazidime, Ceftriaxone, and Cefotaxime. $^{18}$

ESBL is an enzyme that can hydrolyze antibiotics in the Penicillin group, cephalosporins in groups 1,2 , and 3 , and the monobactam group. ${ }^{5}$ Due to its ability to hydrolyze the beta-lactam ring on antibiotics, ESBL does not bind to transpeptidase in the bacterial cell wall. ${ }^{19}$ Ampicillin/Sulbactam is a combination of 


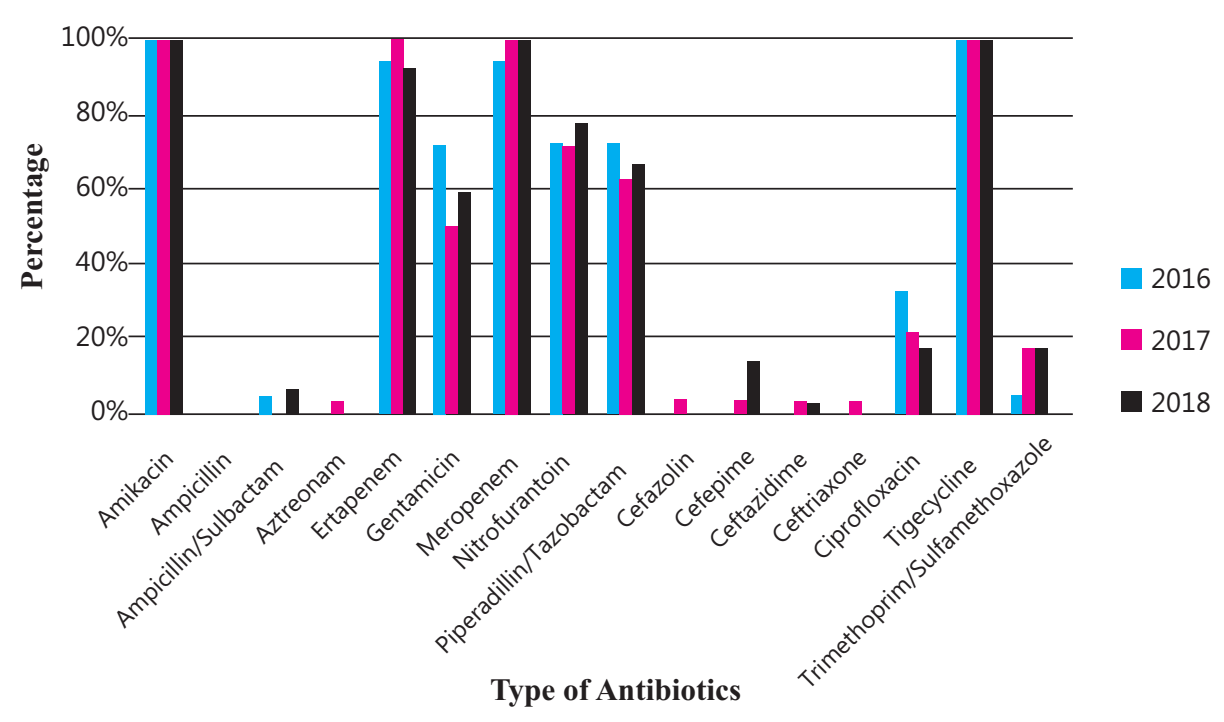

Figure 1. Sensitivity patterns of ESBL-producing E.coli from urine specimens in non-intensive care room in a period of 2016-2018

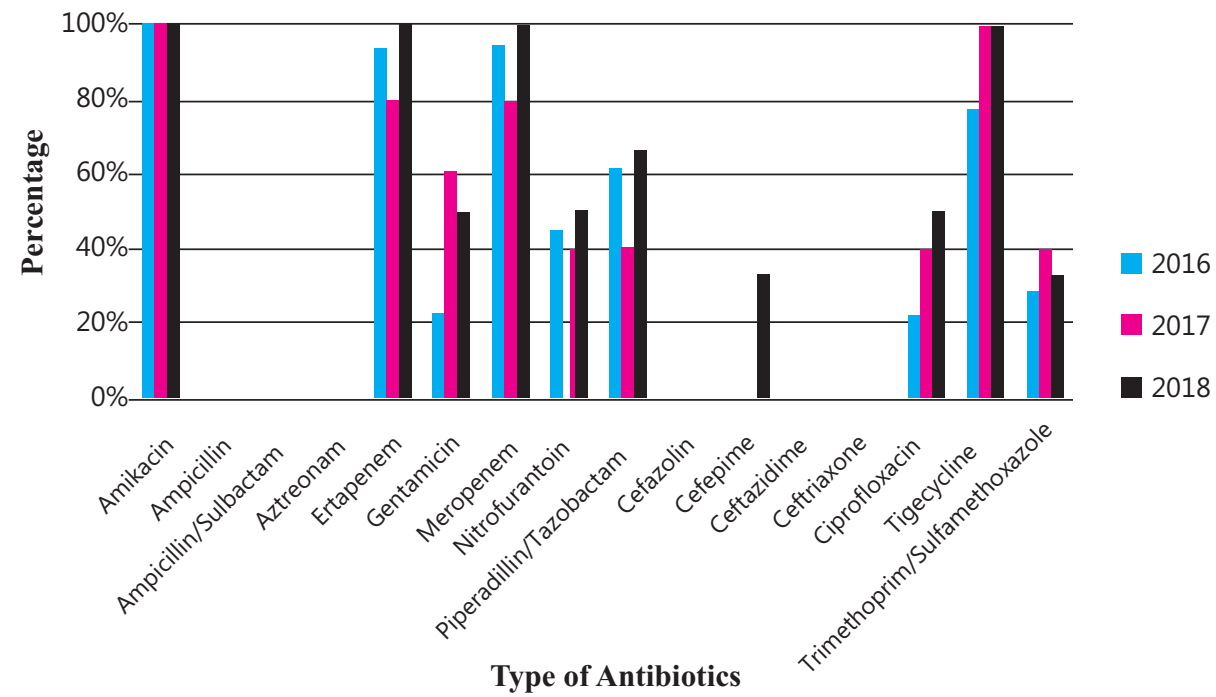

Figure 2. Sensitivity patterns of ESBL-producing K.pneumoniae from urine specimens in non-intensive care room in a period of $2016-2018$

Penicillin-class antibiotics with beta-lactamase inhibitors that can be resistant because it stimulates beta-lactamase production, leading to the hydrolysis of beta-lactams rings and antibiotic resistance. ${ }^{20}$ The presence of antibiotic resistance, especially beta-lactam antibiotics, affects UTI management because broad-spectrum beta-lactam antibiotic is the first line to overcome UTI. ${ }^{21}$ Resistance to beta-lactam antibiotics due to ESBL-producing bacteria will narrow the selection of antibiotics that can be used for the selection of UTI therapy.

Carbapenem (Ertapenem and Meropenem) antibiotics, aminoglycosides (Amikacin), and glycylcyclines (Tigecycline) groups have a high sensitivity to ESBL-producing E.coli and K.penumoniae from year to year. A study in Sharda Hospital India from September 2010 until March 2012 showed that carbapenem and amikacin had a high sensitivity $>70 \%$ to ESBL-E.coli. ${ }^{22}$ The study from an Indian tertiary hospital in January-July 2012 showed that tigecycline had a high sensitivity of $100 \%$ to ESBL-E.coli. ${ }^{23}$ The study from the hospital in Brazil showed that tigecycline had high sensitivity (100\%) to ESBL-E.coli and ESBL K.pneumoniae in the 2015/2016 period. ${ }^{24}$ In addition, a study in an Indian tertiary hospital from July 2013 to June 2014 showed that amikacin and carbapenem had a high sensitivity $(>75 \%)$ to ESBL-K.pneumoniae. ${ }^{25}$ This study was 
solely based on laboratory-based data. Carbapenem-class antibiotics, including ertapenem and meropenem, are broad-spectrum antibiotics that are often used as ultimate weapons by nurses. Indications for the use of antibiotic carbapenem are infections by multiresistant bacteria that remain sensitive to carbapenem. The use of carbapenem should be restricted to avoid the emergence of carbapenem-resistant organisms, such as Carbapenem-resistant Enterobacteriaceae. ${ }^{15,26}$

To prevent resistance, the use of antibiotics is essential. Suitable indication, proper use (duration and frequency) of the drug, and adequate dose are measures of the rational use of antibiotics. Antibiotics are selected based on bacterial sensitivity tests. ${ }^{21}$ In addition, hospitals should involve strategies to minimize the spread of ESBL-producing bacteria with universal precautions and minimize contact among hospitalized patients. Compliance with recommended handwashing techniques or the use of hand rubs can help prevent transmission of infection caused by ESBL-producing bacteria among patients. ${ }^{26}$

\section{CONCLUSIONS AND SUGGESTIONS}

Based on the results of this study, it was concluded that the results of urine test in the non-intensive care room of Ulin General Hospital in the period of $2016-2018$ showed $37.65 \%$ (96 isolates) positive ESBL-producing bacteria, consisting of $69.79 \%$ E.coli (67 isolates) and $30.21 \%$ (29 isolates) K.Pneumoniae. The results of antibiotic sensitivity test against ESBL-producing bacteria from urine test in non-intensive care room of Ulin General Hospital in the period of 2016-2018 showed that Penicillin (Ampicillin), cephalosporins group (Cephazolin, Ceftazidime, Ceftriaxone, Cefepime), monobactam group (Aztreonam), cephalosporin group (Cephazolin, Ceftazidime, Ceftriaxone, Cefepime), monobactam (Aztreonam), cephalosporin group (Cephazolin, Ceftazidime, Ceftriaxone, Cefepime), and the combination of beta-lactam/beta-lactamase inhibitors (Ampicillin/Sulbactam) had high resistance, while the carbapenem antibiotics (Ertapenem, Meropenem), aminoglycoside group (Amikacin), and glycylcyclines (Tigesycline) antibiotics had the highest sensitivity. In addition, carbapenem (Ertapenem, Meropenem), aminoglycoside (Amikacin), and glycylcyclines (Tigesicline) classes can be used to treat infection caused by ESBL-producing bacteria from urine specimens.

Further research on the sensitivity patterns of
ESBL-producing bacteria with samples other than urine was needed. Further research was recommended to use the patient's medical record to determine the diagnosis of patients with urine culture requests in the non-intensive care room. Studies regarding the antibiotic sensitivity pattern of ESBL bacteria in non-intensive care must be conducted periodically to determine the trend of changes in antibiotic sensitivity of ESBL-positive isolates each period. It was expected that the data obtained in this study could be used as a guide in selecting appropriate empirical therapy.

\section{REFERENCES}

1. Prestinaci F, Pezzotti P, Pantosti A. Antimicrobial resistance: A global multifaceted phenomenon. Pathogens and Global Health, 2015; 7: 309.

2. Biutifasari V. Extended Spectrum Beta-Lactamase (ESBL). Oceana Biomedicina, 2019; 1:2-7.

3. Suwantarat N, Carroll KC. Epidemiology and molecular characterization of multidrug-resistant Gram-negative bacteria in Southeast Asia. Antimicrobial Resistance and Infection Control, 2016; 5: 6.

4. Anggraini D, Hasanah U, Andrini F, Savira M, Irawan D, Prima R. Prevalensi dan pola sensitivitas Enterobacteriaceae penghasil ESBL di RSUD Arifin Achmad Pekanbaru. Jurnal kedokteran Brawijaya, 2017; 30: 50.

5. Sah SK, S Hemalatha. Extended-Spectrum Beta-Lactamase (ESBL) mechanism of antibiotic resistance and epidemiology. Pharmtech Research, 2015; 7: 303.

6. Bouassida K, Jaidane M, Bouallegue O, Tlili G, Naija H, Mosbah AT. Nosocomial urinary tract infections caused by extended-spectrum beta-lactamase uropathogens: Prevalence, pathogens, risk factors, and strategies for infection control. Urology, 2016; 10: 89.

7. Khoilidi MM. Pengetahuan keluarga pasien tentang infeksi nosokomial. Ponorogo, Universitas Muhammadiyah Ponorogo. 2015; $1-4$ http://eprints.umpo.ac.id/1286/[Karya Tulis Ilmiah].

8. Washington State Department of Health. Types of hospital units. [Available at: https://www.doh.wa.gov/ ForPublicHealthandHealthcareProviders/Healthcare ProfessionsandFacilities/HealthcareAssociated Infections/HAIReports/TypesofHospitalUnits (accessed 25 Dec, 2018).

9. Indrawan DE. Kejadian infeksi saluran kemih pada pasien pengguna kateter yang dirawat di ruang rawat inap RSUD Dr. H. Abdul Moeloek Bandar Lampung. [Skripsi]. Bandar Lampung, Universitas Lampung, 2015; 3. Available from:https://123dok.com/ document/oz134lpq-prevalensi-infeksi-saluran -pengguna-kateter-dirawat-moeloek-lampung.html (accessed 1 December, 2019)

10. Aboyne M, Tesfaw G, Abdissa A. Isolation of Extended Spectrum B-lactamase (ESBL) producing Escherichia 
coli and Klebsiella pneumoniae from patient with community-onset urinary tract infections in Jimma University Specialized Hospital, Southwest Ethiopia. Canadian Journal of Infectious Disease and Medical Microbiology, 2018; 2018: 3-4.

11. Widianingsih $\mathrm{M}$, Jesus AMD. Isolasi Escherichia coli dari urine pasien infeksi saluran kemih di Rumah Sakit Bhayangkara Kediri. Al-Kauniyah. Biology, 2018; 11: 106.

12. Purnomo BB. Dasar-dasar urologi. Ed ketiga., Jakarta, CV Sagung Seto, 2016; 53-55.

13. Kudinha T. The pathogenesis of Escherichia coliurinary tract infection. In: Samie A, editor. Escherichia coli recent advances in physiology, pathogenesis, and biotechnological applications. ${ }^{\text {st }}$ Ed., Croatia, InTech, 2017; 51.

14. Lakshmi R, Nusrin KS, Ann GS, Sreelakshmi KS. Role of beta-lactamases in antibiotic resistance: A review. International Research Journal of Pharmacy, 2014; 5:37-8.

15. Sutandhio S, Alimsardjono L, Lusida MI. Distribusi dan pola kepekaan Enterobactericeae dari spesimen urin di RSUD Dr. Soetomo Surabaya periode Januari-Juni 2015. Mikrobiologi Klinik, 2015; 1:2-7.

16. Seputra KP, Tarmono, Noegroho BS, Mochtar CA, Wahyudi I, DKK. Guideline penatalaksanaan infeksi saluran kemih dan genitalia pria 2015. Ikatan Ahli Urologi Indonesia, 2015; 2: 5.

17. Grabe M, Bartoletti R, Johansen TEB, Cai T, Çek M, et al. Guidelines on urological infections. European Association of Urology, 2015; 2: 12-59.

18. Zhang $\mathrm{H}$, Johnson A, Zhang G, Yang $Y$, Zhang J, Li D, et al. Susceptibility of Gram-negative Bacilli from hospital-and community-acquired intra-abdominal and urinary tract infections: A 2016-2017 update of the Chinese SMART study. Infection and Drug Resistance, 2019; 12: 910.

19. Muhajir AS, Purwono PB, Handayani S. Gambaran terapi dan luaran infeksi saluran kemih oleh bakteri penghasil extended spectrum beta-lactamase pada anak di RSUD Dr. Soetomo Surabaya. Sari Pediatri,
2016; 18: 114.

20. Adisasmito AW, Tumbelaka AR. penggunaan antibiotik khususnya pada infeksi bakteri Gram-negatif di ICU anak RSAB Harapan Kita. Sari Pediatri, 2006; 8: 132.

21. Endriani R, Anggraini D, Rachmaliza, Wandari R. Bakteri dan multiresisten obat (multi-drugresistance) pada pasien dengan kateter urin di RSUD Petala Bumi Pekanbaru. JIK, 2016; 10: 122-8.

22. Kumar D, Singh AK, Ali MR, Chander Y. Antimicrobial susceptibility profile of Extended Spectrum $\beta$-Lactamase (ESBL) producing Escherichia coli from various clinical samples. Infectious Disease: Research and Treatment, 2014; 7: 1-8.

23. Chauhan S, Mahawal BS, Ramola DC. Extended-spectrum $\beta$-lactamases in urinary isolates of Escherichia coli prevalence and susceptibility pattern at a tertiary care hospital. International Journal of Research in Medical Sciences, 2015; 3: 1623.

24. Oliveira CF. Ferrugem F, Schmidt RV, Prá D, Horta JA. Activity of Carbapenems and Tigecycline against ESBL-producing Escherichia coli and Klebsiella spp. J Bras Patol Med Lab, 2018; 56: 34-5.

25. Singh AK, Jain $S$, Kumar D, Singh RP, Bhatt $H$. Antimicrobial susceptibility pattern of extended-spectrum beta-lactamase-producing Klebsiella pneumoniae clinical isolates in an Indian Tertiary Hospital. Journal of Research in Pharmacy Practice, 2015; 4: 153-9.

26. Fernando MMPSC, Luke WANV, Miththinda JKN, Wickramasinghe RDSS, Sebastiampillai BS, et al. Extended-spectrum beta-lactamase-producing organisms causing urinary tract infections in Sri Lanka and their antibiotic susceptibility pattern-a hospital-based cross-sectional study. Biomed Central Infectious Disease, 2017; 17: 4. 